\title{
Pak een hamer en doe mee! : onderzoek naar het onderwijssysteem in de Academische Werkplaats Onderwijs.
}

Citation for published version (APA):

de Wolf, I. F. (2014). Pak een hamer en doe mee! : onderzoek naar het onderwijssysteem in de Academische Werkplaats Onderwijs. Maastricht University. https://doi.org/10.26481/spe.20141009iw

Document status and date:

Published: 09/10/2014

DOI:

10.26481/spe.20141009iw

Document Version:

Publisher's PDF, also known as Version of record

Please check the document version of this publication:

- A submitted manuscript is the version of the article upon submission and before peer-review. There can be important differences between the submitted version and the official published version of record.

People interested in the research are advised to contact the author for the final version of the publication, or visit the DOI to the publisher's website.

- The final author version and the galley proof are versions of the publication after peer review.

- The final published version features the final layout of the paper including the volume, issue and page numbers.

Link to publication

\footnotetext{
General rights rights.

- You may freely distribute the URL identifying the publication in the public portal. please follow below link for the End User Agreement:

www.umlib.nl/taverne-license

Take down policy

If you believe that this document breaches copyright please contact us at:

repository@maastrichtuniversity.nl

providing details and we will investigate your claim.
}

Copyright and moral rights for the publications made accessible in the public portal are retained by the authors and/or other copyright owners and it is a condition of accessing publications that users recognise and abide by the legal requirements associated with these

- Users may download and print one copy of any publication from the public portal for the purpose of private study or research.

- You may not further distribute the material or use it for any profit-making activity or commercial gain

If the publication is distributed under the terms of Article $25 \mathrm{fa}$ of the Dutch Copyright Act, indicated by the "Taverne" license above, 


\section{Maastricht University}

\section{Inge de Wolf}

School of Business and Economics

\section{Pak een hamer en doe mee!}

Onderzoek naar het onderwijssysteem in de Academische Werkplaats Onderwijs

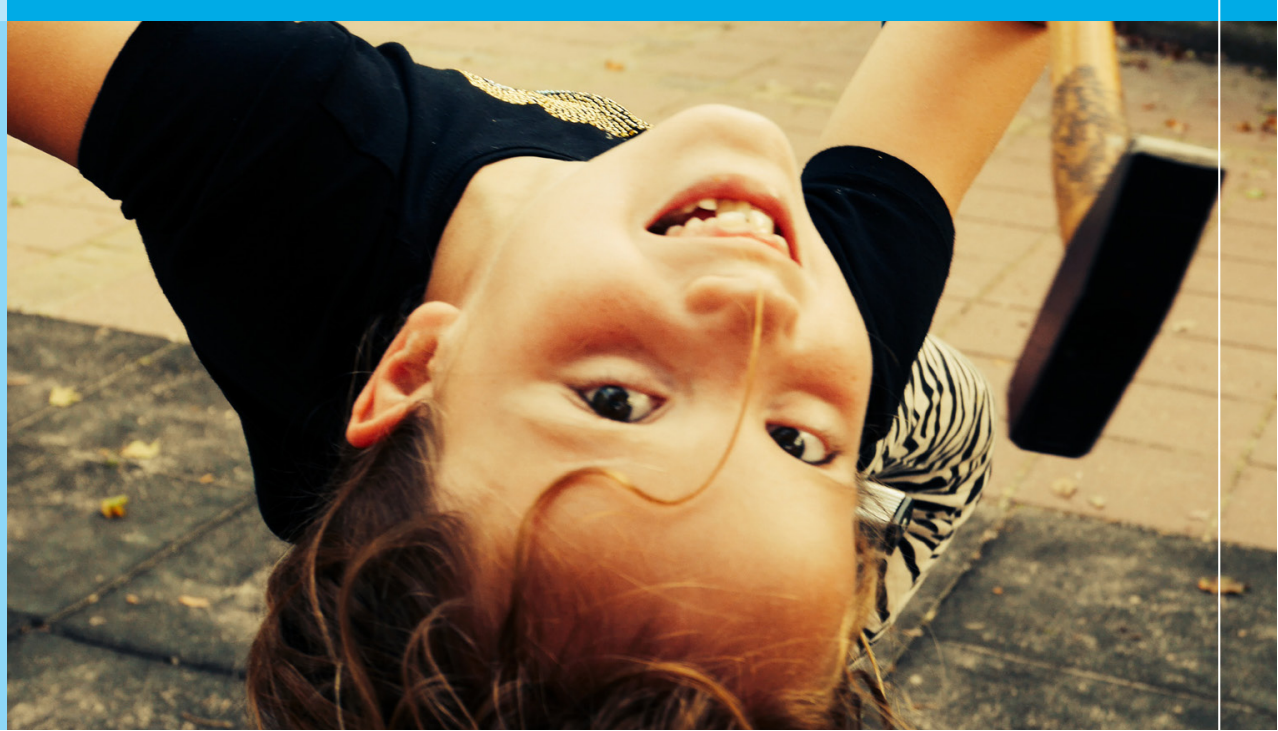




\section{Pak een hamer en doe mee!}

Onderzoek naar het onderwijssysteem

in de Academische Werkplaats Onderwijs 


\section{Colofon}

Ontwerp \& print: Canon Business Services, Maastricht

ISBN: 9789056814397

NUR: 781

Alle rechten voorbehouden. Niets uit deze uitgave mag worden verveelvoudigd, opgeslagen in een geautomatiseerd gegevensbestand of openbaar gemaakt worden, zonder voorafgaande schriftelijke toestemming van de auteur of uitgever. 


\title{
Pak een hamer en doe mee!
}

\author{
Onderzoek naar het onderwijssysteem \\ in de Academische Werkplaats Onderwijs
}

door prof. dr. Inge de Wolf 
Mijnheer de Rector Magnificus,

Dames en heren,

Hoe kunnen we ervoor zorgen dat het onderwijs beter wordt? Hoe ontwikkelen leerlingen zich? Kijken we gedetailleerd genoeg en begrijpen we de mechanismen? Wat werkt wel en wat werkt niet in ons onderwijssysteem? En aan welke knoppen kunnen we draaien om ervoor te zorgen dat leerlingen zich nog beter ontwikkelen?

Om deze vragen te kunnen beantwoorden, is het noodzakelijk dat we niet alleen kijken naar het onderwijs in afzonderlijke scholen, maar juist ook de werking van het onderwijssysteem onderzoeken. Het onderwijssysteem is een samenhangend geheel van leerlingen, scholen en instellingen. Het kan op verschillende niveaus bekeken worden, bijvoorbeeld op het niveau van een gemeente, regio of land. Dit laatste wordt vaak het onderwijsstelsel genoemd.

Kenmerken van een onderwijssysteem worden goed zichtbaar wanneer we individuele leerlingen volgen. Zij kiezen tussen scholen, stromen door naar vervolgopleidingen, wisselen soms van school en merken op de arbeidsmarkt hoe waardevol hun kennis en vaardigheden zijn. Tijdens hun schoolloopbaan hebben ze vooral te maken met leraren, maar indirect ook met het gedrag en beleid van schoolleiders, bestuurders, de gemeente, bedrijven die stages aanbieden, de sociale werkplaats, de onderwijsinspectie, etc. ${ }^{1}$ Deze personen en organisaties hebben vaak verschillende belangen en reageren op prikkels en op elkaars gedrag. Hierdoor kan het voorkomen dat rationeel gedrag op schoolniveau leidt tot suboptimale uitkomsten voor leerlingen (op systeemniveau). ${ }^{2}$ Deze dynamiek maakt het onderwijssysteem een interessant geheel en veel meer dan een eenvoudige verzameling van scholen.

1 Zie ook Hooge, E. (2013) Besturing van Autonomie: Over de mythe van bestuurbare onderwijsorganisaties. Inaugurele rede, Tilburg University, pagina 19.

2 Dit verschijnsel is een bekend fenomeen uit de speltheorie. Een bekend voorbeeld waarbij rationeel gedrag van scholen leidt tot suboptimale uitkomsten in het onderwijssysteem is segregatie. Segregatie kan ontstaan doordat scholen met elkaar concurreren om leerlingen, hun eigen profiel kiezen en leerlingen en ouders kiezen voor 'ons-soort-ouders-scholen' (R. Sikkes, De allerbeste basisschool, 2000). Dit kan leiden tot segregatie tussen scholen, zelfs als dit voor het onderwijssysteem een suboptimale uitkomst is. 
In deze oratie bespreek ik een aantal voorbeelden van internationaal en Nederlands onderzoek naar mechanismen in het onderwijssysteem. Ik wil $u$ hiermee laten zien dat het zinvol is om op een andere manier naar het onderwijssysteem te kijken. Zo bespreek ik een voorbeeld van een werkwijze waar voldoende tijd genomen wordt om een vraagstuk goed te verkennen (1). Hierdoor begrijpen we de complexiteit beter en komen we tot goede onderzoeksvragen. Ook geef ik een voorbeeld van illustraties; datavisualisatie en infographics (2). Met dit voorbeeld wil ik laten zien dat visualisatie ons helpt de complexiteit van het systeem in kaart te brengen en mechanismen beter te begrijpen. Waar het gaat om analyses (3) laat ik de waarde zien van een aanpak waar gedrag en uitkomsten in samenhang worden beschouwd (en er niet alleen naar losse onderdelen gekeken wordt). Tot slot geef ik een voorbeeld van verbeelding (4). Met dit voorbeeld wil ik aantonen dat gedachtenexperimenten en simulaties helpen om tot verbetering van het onderwijssysteem en onderwijsbeleid te komen.

De voorbeelden in deze oratie zijn karakteristiek voor de werkwijze van de Academische Werkplaats Onderwijs. ${ }^{3}$ De Werkplaats is een samenwerkingsverband tussen de Universiteit Maastricht en de Inspectie van het Onderwijs, een onderzoeksamenwerking waarbij we intensief samenwerken met leraren, scholen en bestuurders in het onderwijs. Ik hoop dat u na deze oratie een beeld heeft van ons werk in de Werkplaats en ... dat u zelf ook enthousiast bent geworden om mee te doen!

\section{Verkenning}

Alvorens mechanismen en verklaringen te onderzoeken, loont het de moeite om de tijd te nemen om goede vragen te stellen en een verkennende studie uit te voeren. De verkenning is belangrijk omdat tijd schaars is en er altijd meer vragen zijn dan onderzoek kan beantwoorden. Te vaak moeten we in onderwijsonderzoek achteraf constateren dat het net niet die antwoorden oplevert waarnaar we op zoek zijn.

Fraaie voorbeelden van goede verkenningen komen vaak uit de Verenigde Staten. Een sterk voorbeeld is de verkennende studie van Jacob en Levitt naar mogelijke indicatoren van fraude tijdens toetsafnames op 
scholen. ${ }^{4}$ Jacob en Levitt onderzochten de antwoorden van de leerlingen op toetsen. Ze zochten met name naar ongebruikelijke fluctuaties in toetsscores en opvallende antwoordpatronen. Wanneer alle leerlingen in een klas bijvoorbeeld een reeks identieke antwoorden hadden (zie figuur 1), achtten ze de mogelijkheid van fraude aanwezig. Met een simpele verkennende en beschrijvende analyse laten ze zien dat dit op 4 tot 5 procent van de public schools in Chicago inderdaad voorkwam. Ook tonen Jacob en Levitt aan dat er vaker sprake is van mogelijke fraude wanneer de prikkels voor leraren om te frauderen toenemen, bijvoorbeeld omdat er sprake is van een belonings- of afrekencultuur op basis van de toetsscores. De auteurs gebruikten de analyseresultaten om gesprekken met leraren en schoolleiders aan te gaan over hun mogelijk strategisch gedrag.

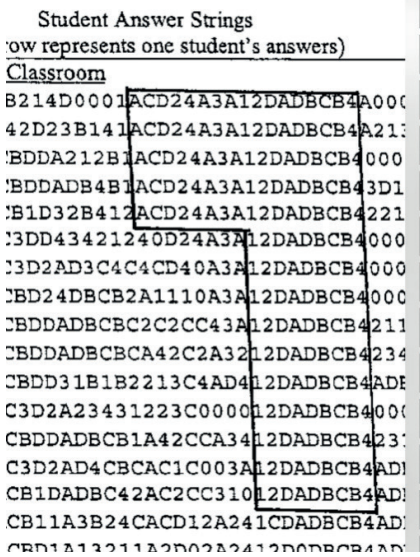

Figuur 1. Identiek antwoordpatroon in klas, mogelijke indicatie van toetsfraude volgens Jacob \& Levitt (2003)

Binnen de Academische Werkplaats Onderwijs werkt Bart Golsteyn aan een onderzoek naar de kwaliteit van leraren. Golsteyn startte zijn onderzoek met een verkenning, waarbij we met leraren, lerarenopleiders, beleidsmakers en inspecteurs spraken over de kwaliteit van leraren in Nederland, over de kwaliteit van de lerarenopleidingen en over de begeleiding van beginnende leraren. Tijdens deze dialoog kwam een veel fundamentelere vraag naar boven; kiezen de juiste personen voor de lerarenopleiding en het lerarenberoep? Deze onderzoeksvraag lijkt

4 Jacob, B.A. \& Levitt, S.D. (2003) Rotten Apples: An Investigation of the Prevalence and Predictors of Teacher Cheating. The Quarterly Journal of Economics, 118 (3): 843-877. 
interessant en buitengewoon relevant. De voorlopige resultaten van het onderzoek wil ik u in deze oratie alvast meegeven.

Figuur 2 geeft inzicht in de rekenvaardigheid van Nederlandse leraren in vergelijking met die van leraren in andere landen. Hiervoor is gebruik gemaakt van de internationale studie PIAAC5, waarin verschillende vaardigheden van volwassenen zijn getoetst (waaronder rekenvaardigheden). Uit figuur 2 is af te lezen in welke mate de rekenvaardigheid van leraren in andere landen afwijkt van die van de Nederlandse leraren. Op de X-as staat een reeks landen (van BElgie tot de UK). Een negatieve score voor een land betekent dat de rekenvaardigheid van de leraren in dat land lager is dan die van de Nederlandse leraren. Opvallend is dat de meeste scores negatief zijn. Dit betekent dat Nederlandse leraren beter kunnen rekenen dan leraren in de meeste andere landen. Leraren in Japan en Noorwegen vormen een uitzondering, zij rekenen beter dan Nederlandse leraren. De rekenvaardigheid van Italiaanse leraren is het laagst van de getoonde landen.

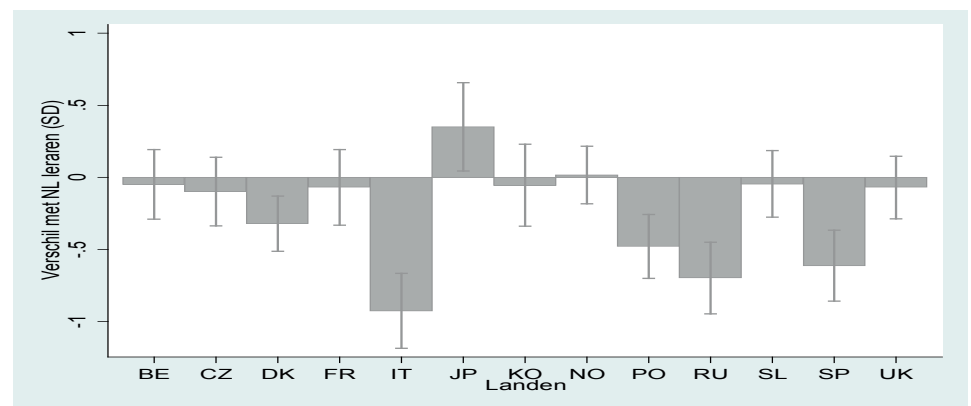

Figuur 2: Verschillen in rekenscores tussen Nederlandse leraren primair onderwijs en leraren primair onderwijs in andere landen (in standaard deviaties) 
De figuren $3 \mathrm{~A}$ en $3 \mathrm{~B}$ laten zien in welke mate leraren beter of slechter rekenen dan de rest van de bevolking in een land. In plaats van de gemiddelde scores tussen leraren en niet-leraren te vergelijken, toont deze grafiek de verschillen in de verdelingen van de scores tussen leraren en niet-leraren. Het voordeel hiervan is dat we kunnen zien welk segment van de bevolking leraar is. ledere lijn in de figuur stelt een land voor, de lijnen tonen de verschilscores voor elk percentiel. Helemaal links staan de verschilscores voor de laagste percentielen, oftewel voor de slechte rekenaars uit beide groepen (leraren en niet-leraren). Rechts staan de verschilscores voor de hoogste percentielen, oftewel de beste rekenaars. Waar de verschilscores positief zijn (de lijn boven de nul ligt), zijn de rekenscores voor de leraren beter dan die van niet-leraren. Wanneer de scores negatief zijn (de lijn onder de nul ligt), zijn de rekenscores van de leraren slechter dan die van de niet-leraren.

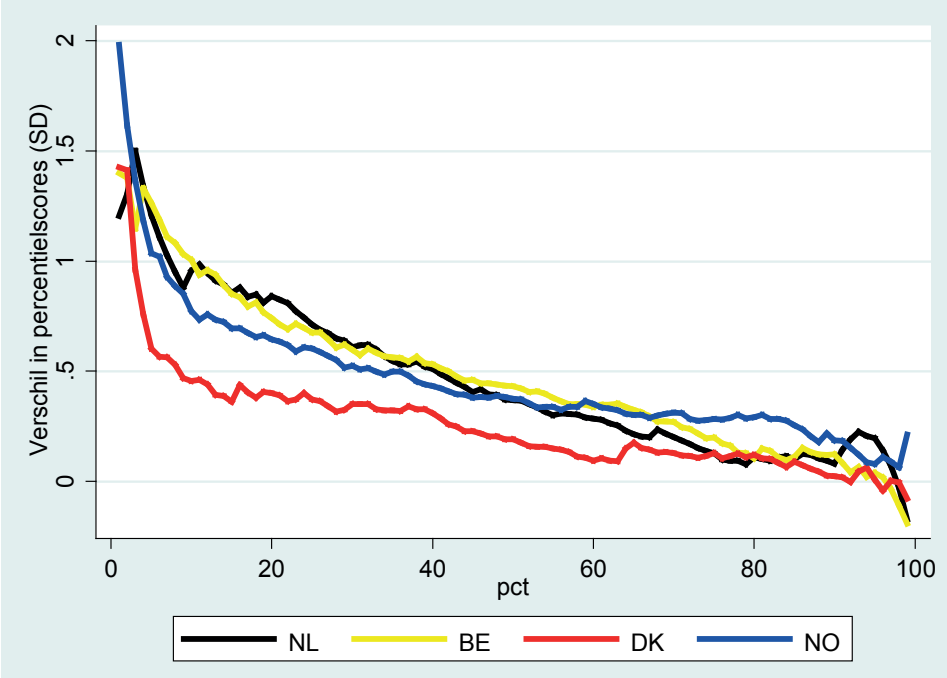

Figuur 3A. De verschillen in verdeling van rekenscores van leraren ten opzichte van alle niet-leraren (voor Nederland, België, Denemarken en Noorwegen) 


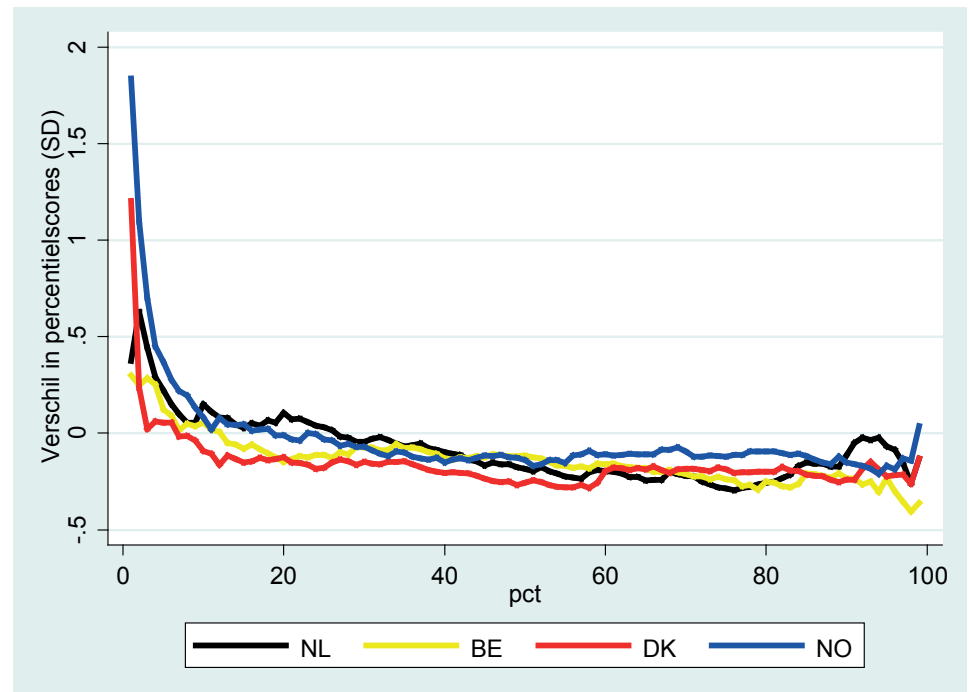

Figuur 3B. De verschillen in verdeling van rekenscores van leraren ten opzichte van HBO-ers en WO-ers (voor Nederland, België, Denemarken en Noorwegen)

De zwarte lijn in figuur 3A geeft de Nederlandse situatie weer. Deze lijn illustreert het verschil in rekenvaardigheid van de Nederlandse leraren ten opzichte van niet-leraren. Uit de figuur blijkt dat de verschilscores voor vrijwel alle percentielen positief zijn. Dit betekent dat Nederlandse leraren beter kunnen rekenen dan de meeste andere Nederlanders. Een vergelijkbaar beeld zien we in België, Denemarken en Noorwegen.

Wanneer we de vergelijking beperken tot personen met een hbo- of een wo-opleiding (figuur 3B), dan komt er een iets ander beeld naar voren. Voor veel, met name de middelste en hogere percentielen, is de score negatief. Dit betekent dat de leraren minder goed rekenen dan andere hbo-ers en wo-ers. Opvallend is verder dat er minder slechte rekenaars onder de leraren te zijn; de onderste 25 procent van de leraren kan beter rekenen dan de onderste 25 procent van alle hbo-ers en wo-ers. Ook dit patroon is vergelijkbaar met dat in België, Denemarken en Noorwegen. 
Wat betekenen deze resultaten nu? Ze geven aan dat leraren beter rekenen dan gemiddeld, maar ook dat ze minder goed kunnen rekenen dan de gemiddelde hbo-er of wo-er. Mogelijk kiezen minder goede rekenaars vaker voor het lerarenvak in plaats van voor een andere opleiding in het hoger onderwijs. Ook kan het zijn dat de opleiding of het beroep verschilt in de mate waarin rekenvaardigheden worden aangeleerd. De komende periode willen we meer inzicht krijgen in de precieze verklaringen van de verschillen. Met dit voorbeeld wil ik nu vooral laten zien dat gesprekken met leraren en het delen van eerste beschrijvende resultaten in dit onderzoek zeer waardevol was. Hiermee kwamen we op een interessante onderzoeksvraag en het hielp ons een goede en betekenisvolle beschrijving van de resultaten maken. Het voorbeeld laat tevens zien dat onderzoek naar de kwaliteit van leraren verder kan komen door onderzoek niet te beperken tot de kwaliteit van de lerarenopleiding en van de lessen, maar hierbij ook keuze- en allocatieprocessen te onderzoeken.

\section{Illustratie}

Goede illustraties van onderzoeksbevindingen helpen het onderwijssysteem beter te begrijpen. De laatste jaren worden steeds vaker datavisualisaties gebruikt om samenhangen en mechanismen in kaart te brengen en systemen beter te begrijpen. Dit geldt niet alleen voor het onderwijs. De hoeveelheid datavisualisaties is de laatste 10 jaar enorm gegroeid en infographics worden steeds fraaier. De toename in aantal en kwaliteit komt voornamelijk doordat zoveel data beschikbaar zijn gekomen en doordat datavisualisaties zo krachtig blijken om zaken beter te begrijpen en inzichtelijk te maken. Ze zijn vaak ook zeer bruikbaar voor een goede dialoog met betrokkenen.

Een van mijn favoriete datavisualisaties is een filmpje uit Nederland van Boven, gemaakt door Frederik Ruys en collega's. Het filmpje gaat over een mantelmeeuw (zie figuur 4). 

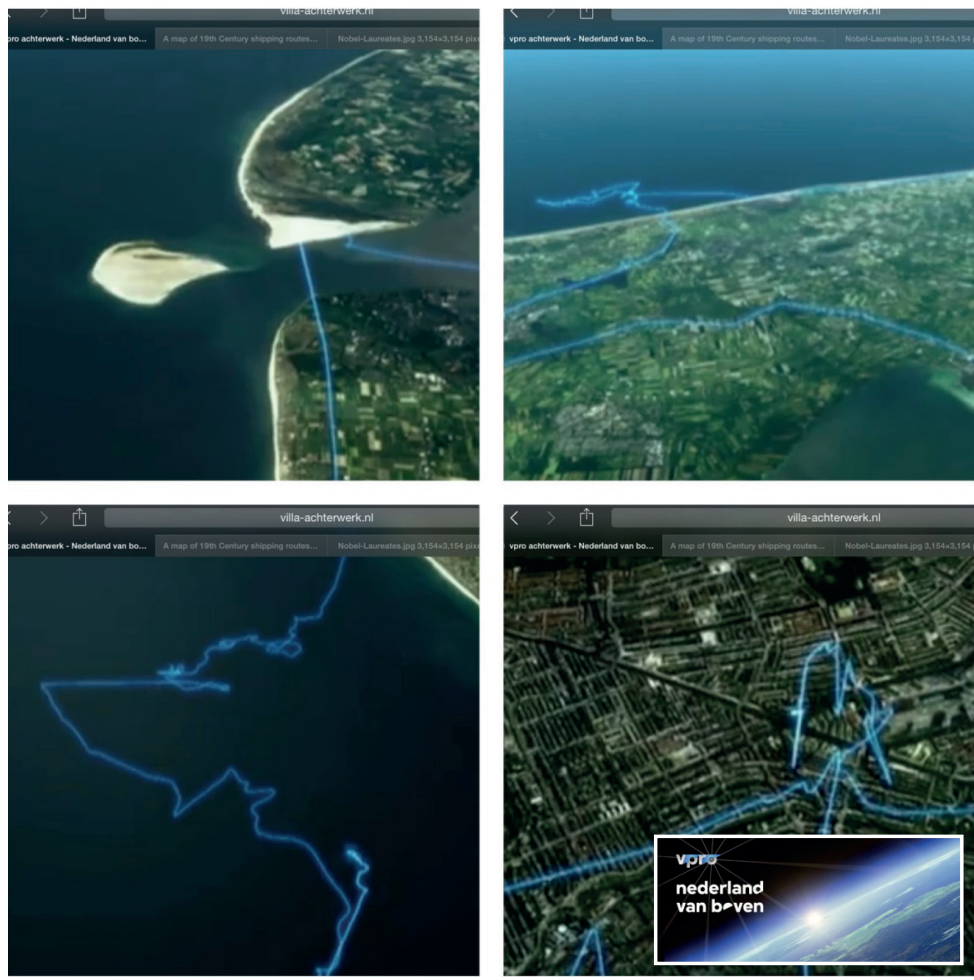

Figuur 4. Beelden van de tocht van een mantelmeeuw, gemaakt door Nederland van Boven.

Wat ik zo bijzonder vind aan dit filmpje, is dat data gebruikt en verzameld worden om op een andere manier naar de mantelmeeuw te kijken. Deze meeuw heeft een GPS-zendertje om z'n poot gekregen, waardoor haar 332-kilometer lange route gevolgd kon worden. Een prachtig idee, dat tegelijkertijd een ander soort informatie oplevert dan foto's of observaties van de mantelmeeuw op Texel en in Amsterdam. Je begrijpt hierdoor beter wat er op een dag gebeurt, welke afstanden de meeuw aflegt en waarom.

In het onderwijs komen ook steeds meer en gemakkelijker gegevens beschikbaar waarmee leerlingen gevolgd kunnen worden. Denk hierbij bijvoorbeeld aan leerlingvolgsystemen van scholen, gemeentelijke registratiebestanden van leerlingen, de bestanden van het onderwijsnummer en registerdata van het Centraal Bureau voor de Statistiek. Hierdoor hoeven analyses niet langer beperkt te blijven tot 
losse observaties van een leerling in een klas of op een school, maar kunnen routes en schoolloopbanen van alle leerlingen gevolgd worden. Hier liggen fantastische nieuwe kansen voor onderwijsonderzoek. Datavisualisaties kunnen helpen om de bulk aan gegevens hanteerbaar te maken en mechanismen beter te begrijpen. Ik verwacht hier de komende jaren veel van en draag met deze leerstoel graag ook bij aan de verdere ontwikkeling hiervan.

Met het beschikbaar komen van betere data over leerlingen wordt het bijvoorbeeld mogelijk de overgang van het basis- naar het voortgezet onderwijs goed in kaart te brengen en op een andere wijze te onderzoeken. Voor leerlingen is de overgang van de basisschool naar de middelbare school een belangrijke stap in de schoolloopbaan. De plaatsing in het voortgezet onderwijs is erg bepalend, onder andere vanwege de toelating tot verder vervolgonderwijs en voor de kans om op het betreffende niveau een diploma te halen. De overgang van het basisonderwijs naar het voortgezet onderwijs is daarmee een van de meest bepalende stappen in de schoolloopbaan van een leerling.

Op onderdelen weten we welke systeemkenmerken belangrijk zijn voor de overgang van het basisonderwijs naar het voortgezet onderwijs. Zo laten internationale vergelijkingen zien dat Nederland zich onderscheidt door de vroege selectie (early tracking) van leerlingen. Ook blijkt dat de vroege selectie leidt tot meer ongelijkheid in het onderwijssysteem, maar dat het effect op ongelijkheid weer kleiner is wanneer in een land ook sprake is van centrale examens. ${ }^{6}$ Van Elk, Van der Steeg en Webbink keken meer in detail naar het onderwijssysteem, namelijk naar plaatsingsgedrag van scholen voor voortgezet onderwijs en de gevolgen daarvan voor de schoolloopbanen van leerlingen. Op basis van toevallige verschillen tussen regionale praktijken laten zij zien dat vroegtijdige selectie een negatief effect heeft op de kans op een diploma voor het hoger onderwijs. ${ }^{7}$ Leerlingen op scholen voor voortgezet onderwijs met een brede brugklas hebben een grotere kans om een diploma in het hoger onderwijs te halen dan leerlingen die direct in een homogene klas instromen.

6 Bol, Thijs, Witschge, Jacqueline, Van de Werfhorst, Herman G. and Dronkers, Jaap (2014). Curricular Tracking and Central Examinations: Counterbalancing the Impact of Social Background on Student Achievement in 36 Countries. Social Forces, 92(4): 1545-1572.

7 Van Elk, R., van der Steeg, M. en Webbink, H.D. (2011) Does the Timing of Tracking Affect Higher Education Completion. Economics of Education Review, 30 (5), 1009-1021. 
Binnen de Academische Werkplaats Onderwijs is de overgang van het basisonderwijs naar het voortgezet onderwijs een belangrijk onderzoeksthema. De afgelopen maanden hebben we hierover een reeks gesprekken gevoerd met een groep leraren, bestuurders van een groot schoolbestuur en schoolleiders uit de regio Maastricht. Tijdens de bijeenkomsten werd duidelijk dat (a) er nog weinig goede cijfers over de overgang van het basisonderwijs naar het voortgezet onderwijs zijn, (b) een deel van de betrokkenen het gevoel heeft dat de uitkomsten voor leerlingen niet altijd optimaal zijn en (c) dat het onduidelijk is welk gedrag (veranderingen in) de uitkomsten veroorzaakt.

Met het beschikbaar komen van registratiegegevens over leerlingen (gegevens gekoppeld aan het onderwijsnummer) kunnen steeds betere illustraties van de overgang van het basisonderwijs naar het voortgezet onderwijs gemaakt worden. Zo is in het recente Onderwijsverslag ${ }^{8}$ van de Inspectie van het Onderwijs in kaart gebracht hoe de overgang van basis- naar voortgezet onderwijs verloopt. Met name enkele infographics, gemaakt door Frederik Ruys, brengen de overgang elegant in kaart.

In figuur 5 staat een serie infographics uit het Onderwijsverslag. Hiermee is de overgang van het basis- naar voortgezet onderwijs gevisualiseerd van vrijwel alle Nederlandse leerlingen die in 2012 drie jaar in het voortgezet onderwijs zaten. ${ }^{9}$ De kolommen geven het niveau van de leerlingen op vier verschillende momenten in de tijd weer, namelijk bij de Eindtoets Basisonderwijs (weergegeven in de $1^{\mathrm{e}}$ kolom), aan het einde van de basisschool (basisschooladvies, $2^{\mathrm{e}}$ kolom), in het eerste leerjaar van het voortgezet onderwijs ( $3^{\mathrm{e}} \mathrm{kolom}$ ) en in het derde leerjaar van het voortgezet onderwijs ( $4^{\mathrm{e}} \mathrm{kolom}$ ). De verschillende niveaus van voortgezet onderwijs zijn gerangschikt en ieder met een eigen kleur weergegeven. De basisberoepsgerichte leerweg is rood, de kaderberoepsgerichte leerweg geel, vmbo-gt is lichtgroen, het havo donkergroen en het vwo is weergegeven in blauw. Aan iedere leerling is op elk van de vier momenten een niveau toebedeeld, afhankelijk van het de eindtoetsscore en het advies van de basisschool, de inschrijving in het voortgezet onderwijs en het overgangs- en plaatsingsbeleid in de eerste jaren van het voortgezet onderwijs.

8 Inspectie van het Onderwijs (2014) De Staat van het Onderwijs 2012-2013. Utrecht.

9 Het betreft hier 83.724 leerlingen (leerlingen waarvan in de registratiebestanden gegevens ontbraken over de eindtoets, het advies en/of de plaatsing in het voortgezet onderwijs zijn niet in de infographic opgenomen). 

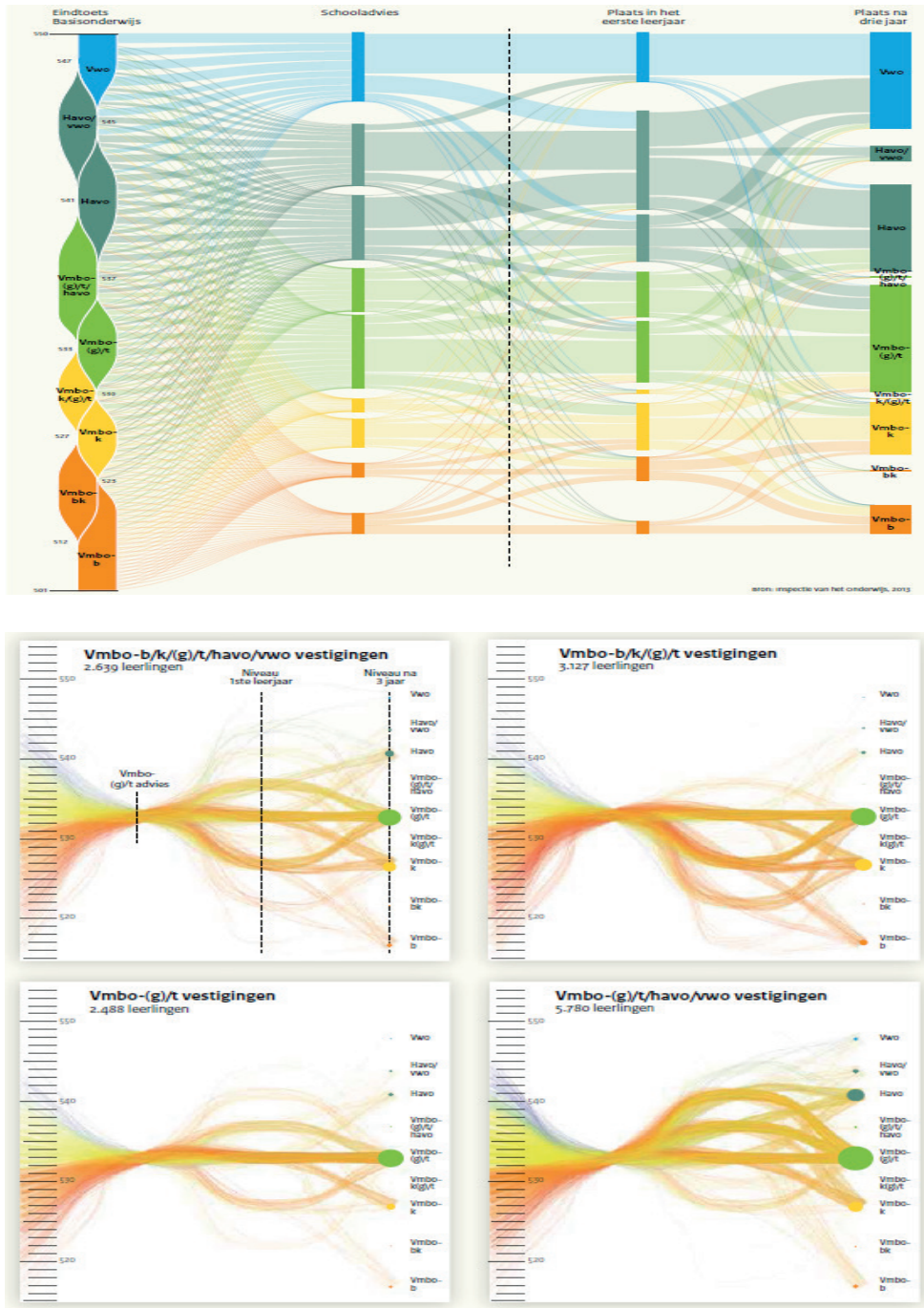

Figuur 5. Infographics over leerlingsstromen van basis- naar voortgezet onderwijs (bron: IvhO, 2014)

De figuur laat zien dat een groot deel van de leerlingen op eenzelfde niveau zit op de vier momenten, maar dat dit lang niet voor alle leerlingen geldt. Tussen elk van de momenten is er bij groepen leerlingen ook sprake van verschuivingen, zowel naar hogere als naar lagere 
onderwijsniveaus. Voor deze leerlingen is de overgang van de basisschool naar het voortgezet onderwijs ingewikkelder. Zo is voor hen de score op de Eindtoets Basisonderwijs ( $1^{\mathrm{e}}$ kolom) slechts ten dele bepalend voor het advies dat zij aan het einde van de basisschool krijgen ( $2^{\mathrm{e}}$ kolom) of komen het advies en de plaatsing op een middelbare school ( $\left.3^{\mathrm{e}} \mathrm{kolom}\right)$ niet overeen. Ook stroomt een deel van deze leerlingen op of af in de onderbouw van het voortgezet onderwijs. Met name vmbo-leerlingen wisselen tijdens de onderbouwperiode veelvuldig van onderwijsniveau.

Uit het onderste deel van figuur 5 wordt ook duidelijk dat de kans op wisselingen in niveau mede afhankelijk is van het type vo-school waarop leerlingen terecht komen en van de samenstelling van de brugklas. In deze figuur staat de overgang voor leerlingen met een advies voor de gemengde/theoretische leerweg van het vmbo. Uit de figuur is af te lezen dat leerlingen vaker van niveau wisselen als hier op hun eigen school mogelijkheden toe zijn. Indien ze starten op een school die naast vmbo-t ook havo en vwo aanbiedt, zitten ze in het derde leerjaar vaker op havo-niveau (of zelfs op vwo-niveau). En wanneer leerlingen met een advies voor de gemengde/theoretische leerweg starten op een brede vmbo-school, zitten ze in leerjaar 3 vaker op kaderniveau. Uit de figuur is ook af te lezen dat de keuze voor het vo-school weer mede-afhankelijk is van de score op de Eindtoets Basisonderwijs.

Figuur 5 illustreert de kracht van infographics. Ze laat daarnaast ook zien dat onderzoek naar het onderwijsstelsel niet beperkt kan blijven tot onderzoek naar leerlingen in klassen en scholen, maar juist ook moet gaan over routes in het onderwijs en overgangen tussen scholen. Schoolovergangen, schoolkeuzepatronen en uitkomsten van allocatieprocessen zijn belangrijke kenmerken van het onderwijssysteem.

\section{Analyse}

Het onderzoeken van effecten en het toetsen van hypothesen is belangrijk in de wetenschap. In onderwijsonderzoek is onderzoek naar effecten en mechanismen extra complex omdat uitkomsten afhankelijk zijn van tal van keuzes van leerlingen en leraren. Selectie-effecten zijn moeilijk te negeren in onderwijsonderzoek en maken het soms moeilijk causale effecten vast te stellen. De leerlingen op school A zijn een ander type leerlingen dan de leerlingen op school B. Dat maakt het bijvoorbeeld moeilijk kwaliteitsverschillen tussen scholen te bepalen en effecten van onderdelen van scholen vast te stellen. 
Een manier om effecten in het onderwijs wel in kaart te brengen en te toetsen, is het doen van experimenteel onderzoek. Het is dan ook niet verwonderlijk dat experimenteel onderzoek in het onderwijs in opkomst is. Ook in Nederland zijn de laatste jaren enkele tientallen experimentele studies uitgevoerd, met name binnen het programma 'Onderwijs Bewijs' ${ }^{10}$ Dit programma stimuleert experimenteel onderwijsonderzoek en 'evidence based' onderwijsinnovatie en financiert een groot aantal experimenten op scholen. Het onderzoeksdesign is bij deze experimenten vaak simpel: een interventie wordt bij een deel van de klassen/scholen gedaan en bij een deel van de klassen/scholen niet (de controlegroep). Verschillen in uitkomsten tussen beide groepen geven inzicht in de effectiviteit van de interventie.

In het overgrote deel van de experimentele onderwijsstudies worden de effecten onderzocht van gerichte interventies in klassen of scholen. Ze worden veel minder vaak gebruikt om interventies in het onderwijssysteem te onderzoeken. Een uitzondering vormt een studie van Hastings en Weinstein (2008), ${ }^{11}$ die onderzoek hebben gedaan naar effecten van informatie op de schoolkeuze van leerlingen en ouders. De auteurs laten zien dat het verstrekken van informatie over scholen in North Carolina (US) resulteert in een kleine verschuiving in schoolkeuze en betere leerprestaties van leerlingen. Binnen de Academische Werkplaats Onderwijs heeft Ulf Zölitz een vergelijkbaar experiment ontworpen. ${ }^{12}$ Hierbij krijgen aankomende basisschoolleerlingen en hun ouders informatie over de kwaliteit en de kenmerken van basisscholen. Het zou interessant zijn om dit experiment ook in Nederland uit te voeren, niet alleen omdat het beter inzicht geeft in schoolkeuze en allocatieprocessen in het onderwijs, maar ook omdat het laat zien hoe gemeenten tot een optimale allocatie kunnen komen en wat de effecten hiervan zijn voor leerlingen en scholen.

Naast experimenten doen onderwijsonderzoekers steeds meer ervaring op met anderegeavanceerde methoden waarmee (causale) mechanismen onderzocht kunnen worden. Hierbijwordt bijvoorbeeld gebruikt gemaakt van gegevens van lotingen die scholen soms bij de toelating hanteren, worden effecten onderzocht bij bepaalde beleidswijzigingen of wordt er

\footnotetext{
10 Zie www.onderwijsbewijs.nl

11 Hastings, J.S. \& Weinstein, J.M. (2008) Information, School Choice, and Academic Achievement: Evidence from Two Experiments. The Quarterly Journal of Economics, Vol. 123, No. 4, pp. 1373-1414.

12 Zölitz, Ulf (2014) The Nature and Consequences of School Choice, dissertatie Universiteit Maastricht, hoofdstuk 5, pp. 97-130.
} 
gebruik gemaakt van andere instrumentele variabelen. Deze technieken maken dat uitgezocht kan worden in welke mate de keuze voor een school bijdraagt aan het succes en geluk van een leerling.

In de Verenigde Staten zijn een aantal fraaie studies gedaan naar schoolkeuze en schoolovergangen waarbij gebruik is gemaakt van gegevens uit lotingen op scholen. Vaak gaat het hierbij om loting bij toelating tot de zogenaamde 'charterschools'. Een artikel van Cullen, Jacob en Levitt onderzoekt het effect van de schoolkeuze van leerlingen op 'high schools' in Chigago. ${ }^{13}$ De auteurs maken gebruik van lotingen bij de toelating. De verwachting is hierbij dat leerlingen die zijn ingeloot beter presteren dan uitgelote leerlingen, vanwege mogelijke kwaliteitsverschillen en een betere match tussen leerling en school. Cullen, Jacob en Levitt vinden enkele kleine positieve effecten op leerprestaties van (ingelote) leerlingen, maar grotere positieve effecten op alternatieve uitkomsten, zoals incidenten en arrestaties. Ingelote leerlingen zijn minder vaak betrokken bij incidenten en worden minder vaak gearresteerd dan de leerlingen die waren uitgeloot en naar andere scholen zijn gegaan.

In enkele grote steden in Nederland vinden ook lotingen plaats, met name voor de toelating op middelbare scholen. Dit gebeurt vooral in steden waar op een deel van de scholen sprake is van overaanmelding, zoals in Amsterdam en Utrecht. In een studie van Ruijs, Oosterbeek en mijzelf gebruiken we de loting in Amsterdam om meer inzicht te verkrijgen in effecten van allocatie en kwaliteitsverschillen tussen scholen voor voortgezet onderwijs. Hiervoor vergelijken we schoolloopbanen van ingelote leerlingen met die van uitgelote leerlingen. De studie laat zien dat op scholen waar geloot wordt een ander type leerlingen instroomt, namelijk leerlingen die beter presteerden in het basisonderwijs en leerlingen die uit een hoger sociaal economische milieu komen. Verder kenmerken de lotingscholen zich door een hoger rendement in de bovenbouw en hogere examenresultaten, maar tegelijkertijd ook door meer zittenblijvers en afstroom in de onderbouw (een lager onderbouwrendement). Een opvallende en onverwachte bevinding is dat de ingelote leerlingen wat vaker dan uitgelote leerlingen blijven zitten en/of naar een klas op een lager niveau gaan. Dit kan te maken hebben met verschillen in overgangs- en platsingsbeleid tussen de

13 Cullen, J.B., Jacob, B.A. and Levitt, S. (2006) The Effect of School Choice on Participants: Evidence from Randomized Lotteries. Econometrica, Vol. 74, No. 5, pp. 1191-1230. 
lotingscholen en de andere scholen, maar andere verklaringen zijn ook mogelijk. Gedetailleerde resultaten en een beschrijving van mogelijke verklaringen kunt $u$ vinden in het proefschrift van Ruijs, dat later dit jaar verschijnt.

Verdelingsmechanismen en allocatie binnen het onderwijssysteem kunnen ook onderzocht worden door naar situaties te zoeken waar selectie-effecten niet of minimaal aanwezig zijn. Een klassiek voorbeeld is een onderzoek van Hoxby, die gebruik maakt van zogenaamde 'natural borders' (zoals rivieren) om het effect van concurrentie tussen scholen te onderzoeken. ${ }^{14}$ Zij gaat er hierbij vanuit dat twee scholen sterker met elkaar concurreren wanneer ze niet gescheiden zijn door bijvoorbeeld een rivier dan wanneer er wel een rivier tussen de scholen ligt. Deze 'natural borders' zijn fraaie instrumenten om in onderzoek te gebruiken, al is er wel kritiek op de manier waarop Hoxby dit heeft gedaan.

Binnen de Academische Werkplaats Onderwijs onderzoekt Ulf Zölitz het effect van schoolkenmerken op schoolkeuze. ${ }^{15}$ Hij gebruikt de afstand tot een school als instrument om selectie-effecten te meten. Hoe groter de afstand tot een basisschool, des te minder ouders geneigd zullen zijn deze school te betrekken bij de schoolkeuze voor hun kind. In regio's met veel basisscholen zijn er dus grote selectie-effecten, in regio's met maar weinig basisscholen zijn er nauwelijks selectie-effecten. Zölitz gebruikt de afstand in meters als maat om selectie-effecten te meten en inzicht te krijgen in de sterkte van de preferenties van ouders. Hij laat bijvoorbeeld zien dat ouders bereid zijn hun kind op een basisschool 190 meter verderop te doen als deze basisschool geen (zeer) zwakke school is. ${ }^{16}$

Voor zorgleerlingen willen we de komende jaren vergelijkbare modellen maken. Hier is de situatie nog wat ingewikkelder omdat leerlingen kunnen kiezen tussen een reguliere school of een school voor speciaal onderwijs (die vaak verder weg is). De uitkomsten van dit keuzeproces zijn weer afhankelijk van de kwaliteit van de ondersteuning op de reguliere school en de extra afstand die overbrugd moet worden wanneer gekozen wordt voor een school voor speciaal onderwijs. Met

\footnotetext{
14 Hoxby, C.M. (2000) Does Competition among Public Schools Benefit Students and Taxpayers? The American Economic Review, Vol. 90, No. 5 (Dec., 2000), pp. 1209-1238.

15 Zölitz, U., Borghans, L. \& Golsteyn, B. (forthcoming) Parental Preferences for Primary School Characteristics. B.E. Journal of Economic Analysis and Policy.

16 Dit betekent dat een leerling tijdens de lagere school ruim $600 \mathrm{~km}$ verder fiets/loopt dan wanneer hij/ zij naar de dichterbij gelegen (zeer) zwakke school was gegaan.
} 
de invoering van passend onderwijs staan veel leerlingen en ouders opnieuw voor deze keuze.

De voorbeelden tonen dat het onderwijssysteem meer is dan een som van de afzonderlijke leerlingen, klassen en scholen. Juist schoolkeuzeprocessen, schoolwisselingen en overgangen tussen scholen zijn van grote invloed op schoolloopbanen van leerlingen. Meer en beter inzicht in deze mechanismen is mogelijk, maakt dat we het onderwijssysteem beter begrijpen en geeft zicht op mogelijkheden voor verbetering. Binnen de Academische Werkplaats willen we rond dit thema nieuw experimenteel onderzoek opzetten en verder zoeken naar alternatieve manieren om (causale) effecten voor het onderwijssysteem in kaart te brengen.

\section{Verbeelding}

Om onderwijssystemen beter te begrijpen, helpt het ook om na te denken over mogelijke alternatieven voor bestaande situaties in het onderwijs. Wat gebeurt er bijvoorbeeld met leerlingen als we ze in het voortgezet onderwijs op een hoger niveau toelaten dan hun advies uit groep 8? Wat gebeurt er met leerlingen als meer scholen kiezen voor homogene brugklassen? Wat betekent het voor leerlingen als we mbo-ers niet meer automatisch toelaten in het hbo? En wat als meer leerlingen met een ondersteuningsbehoefte in het regulier onderwijs komen? Om dit type vragen te beantwoorden zijn twee zaken van groot belang: verbeelding en inzicht in mechanismen binnen het onderwijssysteem.

Inspirerende voorbeelden komen vooral uit onderzoek waarin onderzocht wordt in welke mate de kwaliteit van leraren van invloed is op studiesucces of andere uitkomsten voor leerlingen. ${ }^{17}$ Het eerste voorbeeld dat ik wil noemen is een onderzoek van Chetty, Friedman en Rockoff. ${ }^{18} \mathrm{Zij}$ onderzochten langetermijneffecten van leraren op leerlingen, onder andere door te kijken naar verschillen in salaris tussen oud-leerlingen. De auteurs vonden dat leerlingen die les hadden gehad van goede leraren beduidend meer verdienen dan leerlingen die les hadden gehad van minder goede leraren. Mooi aan hun studie is dat ze zich afvragen wat er zou gebeuren als we de minst goede leraren zouden vervangen door betere leraren. Wat als de minst goede leraren nooit

17 Zie oa Kane \& Staiger (2008) en Hanushek en Rivkin (2010).

18 Chetty, R. Friedman, J.N. en Rockoff, J.E. (2011) The Long-Term Impacts of Teachers: Teacher Value-Added and Student Outcomes in Adulthood. NBER Working Paper No. 17699, December 2011. 
voor het lerarenberoep hadden gekozen of uitgestroomd waren naar een ander beroep? Chetty, Friedman en Rockoff (2011) berekenden dat leerlingen later gemiddeld 250 duizend dollar meer verdienen als de vijf procent leraren met de laagste toegevoegde waarde vervangen wordt door een gemiddelde leraar. Op dit type berekeningen is soms wel wat af te dingen, maar door verbeelding en het spelen met uitkomsten geven de auteurs fraai inzicht in de mogelijke opbrengsten van ander keuze- en allocatiegedrag en/of van beleidsalternatieven.

Een ander inspirerend voorbeeld van verbeelding vormt een studie van Staiger en Rockoff. ${ }^{19}$ Zij onderzochten wat de mogelijkheden zijn om goede leraren te selecteren, aangezien informatie over hoe goed een leraar is in selectieprocedures op scholen veelal ontbreekt. Deze vraag is relevant omdat het voor de leerprestaties (ofwel gerealiseerde leerwinst) van een leerling nogal wat uitmaakt of hij van een goede of minder goede leraar les krijgt. Een standaarddeviatie verschil in toegevoegde waarde van leraren gaat gepaard met 0,1 tot 0,2 standaarddeviatie verschil in leerprestaties van leerlingen. ${ }^{20}$ Staiger en Rockoff beeldden zich een situatie in waar leraren die bij hun leerlingen weinig leerwinst realiseren vervangen worden door nieuwe leraren. Dit heeft een prijs, omdat leerlingen vaak tijdelijk minder leren bij deze nieuwe beginnende leraren. Desondanks levert dit gemiddeld meer leerwinst per leerling op, zo laten de auteurs voor de districten Los Angeles en New York City zien. Ze tonen met behulp van een simulatiemodel dat de gemiddelde leerwinst het hoogst zal zijn wanneer een aanzienlijk deel van de beginnende leraren na 1, 2 of 3 jaar vervangen wordt door nieuwe beginnende leraren. De auteurs bepleiten een systeem waarin leraren met een hoge toegevoegde waarde (leraren waar leerlingen een hoge leerwinst realiseren) gekoesterd worden en vaste posities krijgen. Met hun simulatiemodel zijn ze in staat de uitkomsten van verschillende (beleids)scenario's met elkaar te vergelijken en de gevolgen van maatregelen voor de uitkomsten in een onderwijssysteem uit te rekenen.

Voor Nederland hebben Van der Steeg en Gerritsen de kwaliteitsverschillen tussen basisschoolleraren onderzocht. ${ }^{21}$ Bijzonder aan

19 Staiger, D.O. \& Rockoff, J.E. (2010) Searching for Effective Teachers with Imperfect Information. Journal of Economic Perspectives, volume 24, number 3, pp. 97-118.

20 Zie 12, maar ook Kane, T. \& Staiger, D.O. (2008) Estimating Teacher Impacts on Student Achievement: An Experimental Evaluation. NBER Working Paper 14607.

21 Van der Steeg, M. \& Gerritsen, S. (2013) Teacher evaluations and pupil achievement: Evidence from classroom observations. CPB Discussion Paper 230, Centraal Planbureau, Den Haag. 
hun onderzoek is dat ze de kwaliteit van leraren in kaart brachten aan de hand van evaluaties door professionals die de lessen van de leraren bijwoonden. De auteurs onderzochten de relatie tussen de ingeschatte kwaliteit van de leraar na het lesbezoek en de gerealiseerde leerwinst van de leerlingen (in leerprestaties/toetsscores). De verschillen die Van der Steeg en Gerritsen vonden zijn vergelijkbaar met de verschillen uit Amerikaans onderzoek: een standaarddeviatie verschil in ingeschatte kwaliteit gaat gepaard met o,11 (lezen) tot 0,18 (rekenen) standaardafwijking in leerprestaties van leerlingen. Basisschoolleerlingen die les krijgen van een leraar uit het bovenste kwartiel presteren gemiddeld een half niveau hoger dan leerlingen die les krijgen van een leraar uit het onderste kwartiel. Wanneer dit twee jaar achtereen het geval is, gaat het om een heel niveau verschil, aldus Van der Steeg en Gerritsen.

Graag wil ik u nog een voorbeeld van verbeelding laten zien. Dit voorbeeld gaat over de overgang van het basis- naar het voortgezet onderwijs. Deze overgang is interessant omdat hier verschillende belangen spelen. Basisscholen willen hun leerlingen vaak zo hoog mogelijk plaatsen en worden hierin gesteund door ouders. Middelbare scholen hebben er juist belang bij leerlingen voorzichtig te plaatsen om daarmee teleurstelling en afstroom van leerlingen te voorkomen en ook om goede sier te maken met hoge examencijfers en rendementen naar hun bestuur, in de media of naar de onderwijsinspectie. Ook gemeenten zijn een rol gaan spelen, veel gemeenten hebben afspraken gemaakt met bestuurders van basisscholen en middelbare scholen om de overgang te reguleren. In veel gemeenten is er een centrale inschrijving en verloopt de overgang volgens strakke regels. Zo zijn er algemeen geldende toelatingseisen en wordt er bij overinschrijving veelal centraal geloot tussen leerlingen. Gemeenten lijken hierbij ook zoekende; in veel gemeenten is het beleid de afgelopen jaren vaak een of meerdere malen gewijzigd.

In de eerder gepresenteerde infographic over de overgang van het basisnaar het voortgezet onderwijs, was de plaatsing van leerlingen in het derde leerjaar van het voortgezet onderwijs een belangrijke uitkomst. Deze plaatsing staat ook centraal in figuur 6 . Deze figuur toont de plaatsing in het derde leerjaar voor leerlingen in de steden Maastricht, Amsterdam en Utrecht in 2012 en 2013. ledere kleur geeft een niveau aan, oplopend van groen voor de basisberoepsgerichte leerweg tot geel voor het voortgezet wetenschappelijk onderwijs (vwo). 


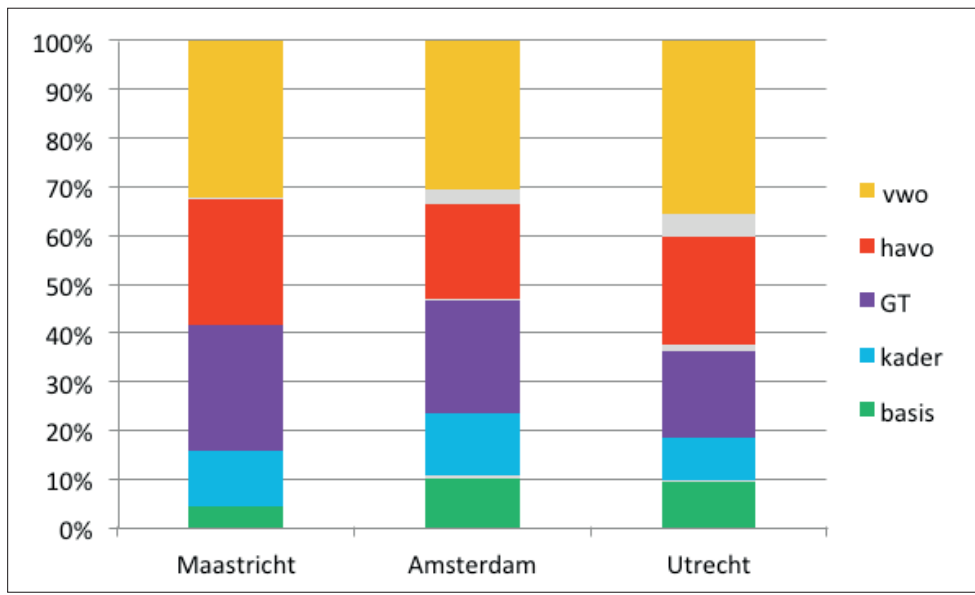

Figuur 6. Plaatsing van leerlingen in derde leerjaar vo in Maastricht, Utrecht, Amsterdam in 2012 en 2013 $(\mathrm{N}=13.473)$

Figuur 6 laat zien dat in Amsterdam een hoger percentage leerlingen op het vmbo zit en in Utrecht juist een lager percentage leerlingen. Dit heeft deels te maken met verschillende leerlingpopulaties; zo wonen in Utrecht meer kinderen van hoger opgeleide ouders. Maar er spelen ook andere factoren mee. De scholen in de drie steden verschillen namelijk in hun adviespraktijken, hun plaatsingsbeleid en hun overgangsbeleid.

Figuur 7 illustreert de verschillen tussen de drie steden in de overgang van het basisonderwijs naar de voortgezet onderwijs. In de figuur staan de percentages leerlingen met een vwo-niveau voor elk van de drie steden. Per stad staat achtereenvolgens weergegeven hoeveel procent van de leerlingen een vwo-niveau had in:

- leerjaar 3 van het voortgezet onderwijs

- leerjaar 1 van het voortgezet onderwijs

- aan het einde van de basisschool (het basisschooladvies)

- bij de score op de Eindtoets Basisonderwijs

Boven in de figuur staan de percentages voor de stad Utrecht. In leerjaar 3 zit 38 procent van de Utrechtse leerlingen op het vwo, in leerjaar 1 was dit 44 procent. Aan het einde van de basisschool kreeg 41 procent een vwo-advies, terwijl 48 procent van de leerlingen een score op de Eindtoets Basisonderwijs had dat voldoende zou zijn voor een vwoadvies. Opvallend aan Utrecht is dat er meer leerlingen op vwo-niveau in 
leerjaar 1 van het voortgezet onderwijs instromen dan je zou verwachten op grond van de basisschooladviezen van de Utrechtse leerlingen. Tussen leerjaar 1 en leerjaar 3 daalt het percentage leerlingen op vwo-niveau. In Utrecht gaan er dus relatief veel leerlingen in de onderbouw van vwo- naar havo-niveau, terwijl het percentage vwo-ers in Amsterdam en Maastricht in de onderbouw juist toeneemt.

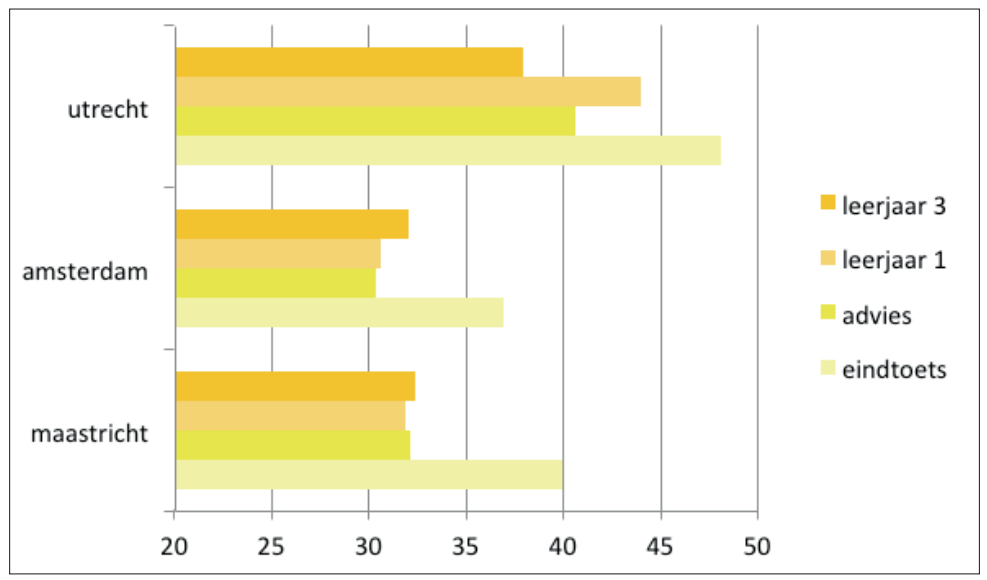

Figuur 7. Percentages leerlingen op vwo-niveau in Amsterdam, Utrecht en Maastricht in leerjaar 3, leerjaar 1, einde basisschool en bij Eindtoets ( $\mathrm{N}=13.473)$

Opvallend zijn verder de verschillen tussen Amsterdam en Maastricht. In beide steden zit een vergelijkbaar percentage leerlingen in leerjaar 3 op het vwo (32 procent). Toch verschilt de allocatie en selectie van leerlingen tussen deze twee steden. In Maastricht is er een relatief groot verschil tussen de score op de Eindtoets Basisonderwijs en het advies aan het einde van de basisschool. Van alle leerlingen heeft 40 procent een score op de Eindtoets op vwo-niveau, maar krijgt 32 procent een vwo-advies. De rest van de overgang is vrij stabiel; in leerjaar 1 en leerjaar 3 zit ook 32 procent van de leerlingen op vwo-niveau. In Amsterdam krijgen ook minder leerlingen een vwo-advies dan we op grond van de score op de Eindtoets zouden verwachten, maar neemt het percentage vwo-ers toe, met name tussen leerjaar 1 en leerjaar 3. Er zijn daar dus meer leerlingen die in de onderbouw van het voortgezet onderwijs opstromen.

De figuren laten duidelijk zien dat de allocatie van leerlingen tussen de drie gemeenten verschilt. Ze geven ons geen goede verklaring van deze verschillen, maar leiden wel tot een prangende vraag: wat als 
er andere keuzes gemaakt waren door ouders, scholen, besturen en door de gemeente? Wat als de leerlingen in Maastricht met een hoge score op de Eindtoets vaker een vwo-advies zouden krijgen, zoals in Utrecht het geval is? Zou Maastricht dan meer vwo-leerlingen krijgen? Waarom stromen er relatief veel leerlingen in Utrecht in leerjaar 1 in een vwo-klas in? En wat als dit er minder zouden zijn, bijvoorbeeld door strengere plaatsingsregels? Zou er in Utrecht dan minder afstroom in de onderbouw zijn? En hoe komt het dan in Amsterdam in de onderbouw van het voortgezet onderwijs meer leerlingen in leerjaar 3 op vwoniveau terecht komen? En meer algemeen: kunnen plaatsingsregels het beste selectief zijn of juist gericht op kansen? En wat betekent dit voor de instroom in het beroepsonderwijs? En wat als de leerlingen in het basisonderwijs in een gemeente allemaal een punt hoger halen op de Eindtoets Basisonderwijs? Wat zou dit betekenen voor de adviezen en de plaatsing in het voortgezet onderwijs en de slaagkansen van leerlingen?

Binnen de Academische Werkplaats Onderwijs willen we deze vragen de komende jaren beantwoorden met behulp van simulatiemodellen. Bestaande adviserings-, toelatings- en plaatsingspraktijken van leerlingen, verschillen tussen gemeenten en veranderingen over de tijd gebruiken we hierbij om de simulatiemodellen te maken. Deze simulatiemodellen helpen inzicht te krijgen in de mogelijke gevolgen van veranderingen in keuzegedrag bij ouders, leerlingen, scholen, besturen en gemeenten op de onderwijskansen en het onderwijssucces van leerlingen.

Met de simulatiestudies willen we binnen de Academische Werkplaats Onderwijs beter in beeld krijgen wat de effecten zijn van kleine verschuivingen binnen en tussen scholen op de uitkomsten van het onderwijssysteem (in een stad of op stelselniveau). Ook maken simulatiemodellen het mogelijk optimale allocatieprocessen te bepalen. Dit helpt scholen en overheden om afspraken te maken en beleid te verbeteren. Simulatiestudies maken de gevolgen van veranderingen inzichtelijk, ze helpen ons om de gevolgen van verschillende keuzes in te beelden. Hiermee zijn ze van groot nut in de dialoog met schoolleiders, bestuurders en overheden.

\section{Onderzoek naar het stelsel}

In deze oratie heb ik een pleidooi gehouden voor een scherpere kijk op de kwaliteit van ons onderwijsstelsel. De voorbeelden die ik u gaf tonen 
aan dat een oppervlakkige blik onvoldoende is om ons onderwijsstelsel goed te begrijpen. Trends van gemiddelden en de ontwikkelingen op scholen vertellen ons onvoldoende over de sterke en zwakke onderdelen van ons stelsel. Om hier wel zicht op te krijgen, moeten we beter kijken en onderzoek doen naar mechanismen in het onderwijsstelsel. Goede onderzoeksvragen, beschrijvende analyses en infographics, onderzoek naar allocatie en causale mechanismen en simulatiemodellen vormen belangrijke onderdelen van dit onderzoek naar het stelsel. Ingewikkelde vragen en designs moeten we hier niet uit de weg gaan. Dialoog tussen wetenschap, veld en beleid zal helpen de complexiteit te reduceren.

Binnen de UniversiteitMaastrichtwillenwe met dialoogensamenwerking een nieuwe vorm van wetenschappelijk onderwijsonderzoek opzetten, een traditie waarin wetenschappelijk onderzoek van hoog niveau hand in hand gaat met praktijk- en beleidsgericht onderzoek. Voorbeelden uit het buitenland die ons inspireren zijn het Centre for Education Policy Analysis (prof. Loeb, Stanford University), het Centre for Economics of Education (prof. Machin, University of London) en het Education Innovation Laboratory (Prof. Fryer, Harvard University). In deze instituten zien we wetenschappelijk onderzoek van zeer hoog niveau, studies gebaseerd op uitstekende data en geavanceerde onderzoeksdesigns en relevant en invloedrijk onderzoek. Voor het veld en voor het beleid komen hiermee tal van nieuwe inzichten vrij waarmee men aan de slag kan gaan om het onderwijs verder te verbeteren.

In Nederland bestaat dit type samenwerkingsverbanden vooral in de medische wetenschappen, ze worden daar academische werkplaatsen genoemd. Voor ons zijn de 'Academische Werkplaats Publieke Gezondheidszorg' en de 'Academische Werkplaats Toezicht' inspirerende voorbeelden. In het onderwijsonderzoek werken wetenschappers ook steeds vaker nauw samen met het scholenveld en beleidsmakers. ${ }^{22}$ In de 'Academische Werkplaats Onderwijs' gaan we een stap verder en is er sprake van een gemeenschappelijke organisatie en onderzoeksprogrammering. Inhoudelijk onderscheidt de Werkplaats zich door haar focus op het onderwijssysteem en op mechanismen binnen dit systeem. ${ }^{23}$

22 Voorbeelden zijn het Top Institute of Evidence Based Education Research (TIER, UVA/RUG/UM), het Centrum voor Brein en Leren van de Vrije Universiteit en de Kenniswerkplaats Rotterdams Talent. 
De focus op het onderwijssysteem (en daarmee het onderwijsstelsel) is niet toevallig en heeft te maken met de betrokkenheid van de Inspectie van het Onderwijs als mede-initiatiefnemer van de Werkplaats. De Inspectie van het Onderwijs kent een lange traditie in het onafhankelijk monitoren van de kwaliteit van het onderwijsstelsel. Zij rapporteert hier jaarlijks over in de 'Staat van het Onderwijs' (het Onderwijsverslag) en in verschillende themarapporten. De 'Staat van het Onderwijs' bestaat ruim twee eeuwen; alle delen van het Onderwijsverslag zijn integraal te downloaden. ${ }^{24}$ Lang niet alle toezichthouders maken een 'staat van', wel groeit het aantal dat aan monitoring en analyse van bijvoorbeeld sectoren doet. De Wetenschappelijke Raad voor Regeringsbeleid hield hier onlangs nog een pleidooi voor en bepleitte dat reflectieve toezichthouders agenderen, spiegelen en actief het debat voeren over 'de staat van de sector'. ${ }^{25}$ Tegelijkertijd constateert de WRR dat nog weinig inspecties zo'n brede 'staat van' publiceren en de onderwijsinspectie daarmee een bijzondere positie inneemt. ${ }^{26}$ Deze bijzondere positie geldt met name het onafhankelijke karakter van het Onderwijsverslag. Zo stond onlangs in het hoofdredactionele commentaar van de Volkskrant het volgende: 'Opdat de inspecteurs minstens een keer per jaar de volledige vrije hand hebben om misstanden die zij zien met de buitenwereld te delen. Voordat zij er zelf onderdeel van worden'.27 De onderwijsinspectie werkt momenteel aan een nieuw ontwerp van 'stelseltoezicht' en verbeterde methoden van stelselevaluatie. Het onderzoek binnen de leerstoel richt zich op dit laatste, de verbeterde methoden van stelselevaluatie. Deze moeten leiden tot nieuwe inzichten in de kwaliteit van het onderwijsstelsel. Nieuwe methoden maken het niet alleen mogelijk om problemen in het onderwijsstelsel beter te analyseren, maar leggen ook onderliggende mechanismen bloot. Hiermee komen mogelijke oplossingen in zicht, waardoor de inspectie de verschillende actoren in het onderwijsstelsel actief aan kan zetten tot verbetering. Ik hoop met het verder ontwerpen en ontwikkelen van onderzoek naar het onderwijsstelsel actief bij te dragen aan een methodologische basis voor deze ontwikkeling in het toezicht, voor de onderwijsinspectie en voor andere toezichthouders.

\footnotetext{
24 Alle 214 onderwijsverslagen zijn integraal te vinden op www.onderwijserfgoed.nl 25 raad voor regeringsbeleid (2013) Toezien op publieke belangen, Den Haag, pagina 16.

26 WRR, pagina 136 en 137.

27 VK, hoofdredactioneel commentaar 18 juni 2014.
} 
Thema's waar het onderzoek van de Academische Werkplaats Onderwijs zich onder andere op wil richten zijn schoolloopbanen, overgangen in het stelsel, leraren, zorgleerlingen en het curriculum. Op www.academischewerkplaatsonderwijs.nl vindt $u$ de eerste onderzoeksresultaten en kunt $u$ zien hoe we daartoe gekomen zijn.

Ik kijk er erg naar uit de stelselvraagstukken in de komende jaren samen met leraren, schoolleiders, de collega's van de Universiteit Maastricht en collega's van de onderwijsinspectie verder te onderzoeken. Alleen gezamenlijk kunnen we de mechanismen ontrafelen die inzichten opleveren waarmee we ons onderwijsstelsel kunnen verbeteren. Ik nodig u graag uit bij dit avontuur.

PAK EEN HAMER EN DOE MEE! 


\section{Dankwoord}

Vandaag had ik hier niet gestaan zonder de inspiratie, lessen en steun van velen van jullie. Ik ben jullie hier zeer dankbaar voor.

Het College van Bestuur van de Universiteit Maastricht, de decaan van de School of Business and Economics en het bestuur van de vakgroep Algemene Economie 2 wil ik danken voor het instellen van deze bijzondere leerstoel en het in mij gestelde vertrouwen. Voor hun steun aan de leerstoel dank ik ook de inspectieleiding, Annette Roeters, Arnold Jonk en Monique Vogelzang, en de directeur Kennis, Bert Bulder, van de Inspectie van het Onderwijs. Jullie durven met wetenschap en onderwijsveld samen een nieuwe vorm van stelseltoezicht te ontwerpen. Dit getuigt van vertrouwen en lef. Dank hiervoor.

Met Lex Borghans heb ik de Werkplaats opgezet. Lex, zonder jou had ik hier niet gestaan. Tijdens wandelingen door Maastricht bedachten we opzet, onderzoeksprogramma en werkwijze. Ik hoop dat er nog vele kilometers volgen. Louise, Bart, Trudie, Esmee, Maarten en andere collega's van de werkplaats, jullie hebben met de conferentie vandaag laten zien dat de Academische Werkplaats Onderwijs een feit is. Ik kijk ernaar uit de komende jaren met jullie verder te bouwen en samen onderzoek te doen.

Mijn academisch werk had ik de afgelopen jaren nooit kunnen blijven doen als ik bij de Inspectie van het Onderwijs niet met zo'n bijzonder team had gewerkt. Inspectie-collega's, ik geniet van jullie drang om het onderwijs te verbeteren. Hoogtepunten voor mij blijven het maken van het onderwijsverslag en andere stelselactiviteiten, met name omdat we elkaar daar als team blijven inspireren met nieuwe inzichten, kritische vragen, steeds betere analyses en fraaie infographics. Arnold, Machteld, Evelien en andere collega's, dank!

Inspiratie haal ik ook uit de onderzoekssamenwerking met andere wetenschappers. Collega's, ik hoop dat we samen onderzoek blijven doen. Voor mij is mijn tijd aan de Universiteit van Amsterdam, bij het Top Institute of Evidence Based Education Research (TIER) en haar voorganger SCHOLAR ook zeer belangrijk geweest omdat ik daar als wetenschapper verder heb kunnen ontwikkelen. Hessel en andere collega's, dank! Jullie maakten het ook mogelijk naar Stanford University te gaan. Daar heb 
ik ervaren dat wetenschap, veld en beleid elkaar kunnen inspireren en versterken en is mijn droom ontstaan om een Academische Werkplaats te starten.

Buiten mijn directe collega's zijn er nog vele anderen die me inspireren. In het bijzonder wil ik de collega's van VIDE bedanken. Van jullie leer ik bijzonder veel over het toezichtvak en jullie helpen toezicht en wetenschap te verbinden. En Ferdinand Mertens, jouw wijze lessen en kritische vragen zetten me steeds weer aan tot nadenken en betere ontwerpen. Bijzonder veel leer ik ook van Aicha, mijn mentorleerling. Aicha, dank dat je met me deelt wat de overgang van de basisschool naar een nieuwe (VMBO-)school voor jou betekent.

Vrienden, familie, mam .... ook jullie wil ik hartelijk danken. Het doet me veel dat jullie vandaag naar Maastricht zijn gekomen. Mijn laatste woorden zijn voor Eline, Ines en Matthijs. Eline, jij zit in een bijzonder jaar; een nieuwe start, een nieuwe klas, een nieuwe school. Gelukkig blijft er tijd voor het ontwerpen van prachtige schema's, infographics, animatiefilmpjes en websites. En Ines, jouw lef is een groot goed. Zelfs als toch bang bent, besluit je dit niet te zijn. Dit ontroert. Jullie zijn top, meiden. Matthijs, de man in dit prachtgezin, je steun op alle terreinen is bijzonder. En gelukkig blijf je me steeds weer uit m'n werkkamer lokken voor een uitje, muziek of goede film.... zelfs tijdens het schrijven van deze oratie.

Ik heb gezegd. 
